\title{
Expression of 1alpha-HYD and 24-HYD in bovine kidney mediated by vitamin $D_{3}$ supplementation
}

\author{
L.R. Rezende ${ }^{1}$, E.F. Delgado ${ }^{1}$, A.R.L. Júnior ${ }^{2}$, G. Gasparin ${ }^{1}$, \\ E.C. Jorge ${ }^{3}$, G.B. Mourão ${ }^{1}$ and L.L. Coutinho ${ }^{1}$
}

${ }^{1}$ Departamento de Zootecnia, Escola Superior de Agricultura Luiz de Queiroz, Universidade de São Paulo, Piracicaba, SP, Brasil

${ }^{2}$ Departamento de Ciências Básicas,

Faculdade de Zootecnia e Engenharia de Alimentos, Universidade de São Paulo, Pirassununga, SP, Brasil

${ }^{3}$ Departamento de Morfologia, Instituto de Ciências Biológicas, Universidade Federal de Minas Gerais, UFMG, Belo Horizonte, MG, Brasil

Corresponding author: L.L. Coutinho

E-mail:1lcoutinho@usp.br

Genet. Mol. Res. 12 (4): 6611-6618 (2013)

Received March 21, 2013

Accepted October 12, 2013

Published December 11, 2013

DOI http://dx.doi.org/10.4238/2013.December.11.12

\begin{abstract}
In order to better understand vitamin $\mathrm{D}_{3}$ in cattle metabolism, we quantified lalpha-HYD and 24-HYD gene expression. In the kidneys of 35 male Nellore cattle, these were divided into a control group and two treatment groups $\left(2 \times 10^{6}\right.$ international units of vitamin $\mathrm{D}_{3}$ administered for 2 or 8 consecutive days pre-slaughter). Vitamin $\mathrm{D}_{3}$ supplementation resulted in a significant increase in lalpha-HYD gene expression; however, significantly increased 24-HYD gene expression was only detected in cattle that had 8 days of supplementation. The finding of upregulation of 24-HYD due to vitamin D supplementation is in line with the expected rise in 24,25-di-hydroxy-vitamin $\mathrm{D}_{3}$ synthesis observed when plasma vitamin $\mathrm{D}_{3}$ concentrations are high, stimulating excretion by the organism. On the other hand, upregulation of lalpha-HYD was unexpected, since
\end{abstract}


vitamin $\mathrm{D}_{3}$ supplementation has been reported to impact these two genes in opposite directions. We conclude that vitamin $\mathrm{D}_{3}$ metabolism in these animals is more complex than previously reported.

Key words: Gene expression; Kidney; Bovine; Calcium

\section{INTRODUCTION}

Vitamin D occurs in two forms: vitamin $\mathrm{D}_{2}$ (ergocalciferol) and vitamin $\mathrm{D}_{3}$ (cholecalciferol). In animal tissue, sunlight exposure converts 7-dihydro-cholesterol present under the skin into vitamin $\mathrm{D}_{3}$ (Gaman and Sherrington, 1981; Bondi, 1988; Robert et al., 2002). A major function of vitamin $\mathrm{D}$ in the body is the regulation and maintenance of serum calcium and phosphorus homeostasis, by increasing intestinal calcium uptake and minimizing renal loss of these minerals, with the aim of normal bone mineralization (Gaman and Sherrington, 1981).

Synthesis of the major circulating form of vitamin D, 25-hydroxyvitamin $\mathrm{D}_{3}[25(\mathrm{OH})$ $\mathrm{D}_{3}$ ] is catalyzed by the hepatic enzyme vitamin D-25-hydroxylase $(25-H Y D)$. The subsequent fate of $25(\mathrm{OH}) \mathrm{D}_{3}$ is determined mainly by two renal enzymes, vitamin D-24-hydroxylase (24-HYD) and 25-hydroxyvitamin D-1 $\alpha$-hydroxylase (lalpha-HYD). [25(OH)D $\mathrm{D}_{3}$ bound to its serum transport protein (transcalciferin) is carried to the kidneys where hydroxylation by the action of the mitochondrial enzyme lalpha-HYD occurs, forming 1,25 dihydroxyvitamin $\mathrm{D}_{3}$ $\left[1,25(\mathrm{OH})_{2} \mathrm{D}_{3}\right]$, the physiologically active form of vitamin $\mathrm{D}$ (Robert et al., 2002). 1alpha$H Y D$ is an enzyme of renal origin, also found in bone and placenta, activated directly by parathyroid hormone (PTH) due to a decrease in serum phosphate, or indirectly due to decreased concentration of calcium ions in the plasma (Jones et al., 1998). Although 1alpha$H Y D$ activity has been demonstrated at several ectopic sites, circulating levels of $1,25(\mathrm{OH})_{2} \mathrm{D}_{3}$ appear to reflect the expression of this enzyme in the kidney.

24-HYD expression appears to occur in all vitamin D responsive tissues and the function of this enzyme remains somewhat unclear (Omdahl and May, 1997). On the one hand, under higher levels of $1,25(\mathrm{OH})_{2} \mathrm{D}_{3}, 24-H Y D$ acts as a negative regulatory enzyme which, through side chain hydroxylation reactions, inactivates $1,25(\mathrm{OH})_{2} \mathrm{D}_{3}$. The lalpha-HYD and 24-HYD enzyme pathways act synergistically to maintain optimal levels of physiologically active vitamin D (Henry, 1997).

Supplementation with vitamin D has been used in cattle to increase meat tenderness. However, results are not clear and could be dependent on the animal's ability to inactivate excess vitamin $\mathrm{D}$. The details of the mechanisms regulating the level of $1,25(\mathrm{OH})_{2} \mathrm{D}_{3}$, especially in response to dietary factors, are not clear in cattle. In this study, quantitative real-time PCR was used to check whether there is renal regulation of mRNA levels of the lalpha-HYD and 24-HYD genes under different conditions of vitamin $\mathrm{D}_{3}$ supplementation. This work aimed to determine whether an interaction between vitamin $\mathrm{D}_{3}$ supplementation and sunlight exposure conditions could promote differential expression of lalpha-HYD and 24-HYD genes.

\section{MATERIAL AND METHODS}

\section{Experimental conditions}

We used a randomized complete block design (three different categories of initial 
body weight after a period of adaptation to high concentrate diet) under a 3 x 2 factorial arrangement, with 3 regimens of vitamin $\mathrm{D}_{3}$ supplementation and 2 systems of sunlight exposure, resulting in 6 treatments with 7 replications. For the data of expression of specific genes from bovine kidney, 3 treatments lost 2 parcels each, leaving 5 replicates for each treatment and 1 lost one parcel, leaving 6 replicates (35 animals). A linear mixed model was used to perform this combined analysis, in which the effect of vitamin $\mathrm{D}_{3}$ supplementation, sunlight exposure conditions, and their interactions were considered to be fixed, while the effect of blocks nested within the effect of the sunlight exposure conditions was considered to be random.

\section{Animals}

Nellore cattle (Bos indicus) from a commercial herd were used. They had an average weight of $435 \mathrm{~kg}$ and average age of 30 months. After adaptation to a high-concentrate diet, the animals were divided into three weight groups (light $=376 \pm 29 \mathrm{~kg}$, intermediate $=403$ $\pm 16 \mathrm{~kg}$, and heavy $=457 \pm 17 \mathrm{~kg}$ ), which represented the different growth potentials before the beginning of the experimental feedlot period. The animals within each weight group were randomly assigned to the six treatments (three levels of vitamin $\mathrm{D}_{3}$ supplementation $\mathrm{x}$ two sunlight exposure conditions).

\section{Treatments}

After a 56-day period of adaptation to a high-concentrate diet, the animals were confined for 45 days with different sunlight exposure conditions. On the 25 th day of exposure to different sunlight exposure conditions, all animals were conditioned to receive part of their diet in a small trough to simulate the vitamin $\mathrm{D}_{3}$ supplementation procedure, before receiving the remaining portion of the diet. On the 37 th or 43rd day at the feedlot, the animals began supplementation with vitamin $\mathrm{D}_{3}$ for 8 or 2 days respectively.

The animals were housed in individual pens to permit control of consumption, especially of vitamin $\mathrm{D}_{3}$, and received the following treatments: 1) no vitamin $\mathrm{D}_{3}$ supplementation (Vit. 0) and no shade $(\mathrm{N}=6) ; 2)$ Vit. 0 with shade (50\% UV filtration ratio) $(\mathrm{N}=7) ; 3) 2 \times 10^{6}$ IU vitamin $\mathrm{D}_{3}$ for two consecutive days prior to slaughter (Vit. 2) and no shade $\left.(\mathrm{N}=5) ; 4\right)$ Vit. 2 with shade $(\mathrm{N}=5) ; 5)$ with $2 \times 10^{6} \mathrm{IU}$ vitamin $\mathrm{D}_{3}$ for eight consecutive days prior to slaughter (Vit. 8) and no shade ( $\mathrm{N}=7)$; and 6) Vit. 8 with shade $(\mathrm{N}=5)$. Vitamin $\mathrm{D}_{3}$ was given orally, mixed with the concentrate. After slaughter, tissue samples of kidneys (cortex) were collected, frozen in liquid nitrogen and stored at $-80^{\circ} \mathrm{C}$ until extraction of total RNA.

\section{RNA extraction and cDNA synthesis}

Total RNA was isolated using Trizol (Invitrogen, Carlsbad, CA, USA) following manufacturer instructions. Total RNA concentration was determined by spectrophotometry (HITACHI, U-200) and integrity was verified by $1 \%$ agarose electrophoresis. Reverse transcription was performed using $1 \mu \mathrm{g}$ total RNA and the ImProm-II Reverse Transcription System kit (Promega, Madison, WI, USA) as described by the kit manufacturer. After completion of reactions, each cDNA was diluted 1:4 using DNase- and RNase-free water. 


\section{Gene expression analysis}

Primers were designed using Primer3 software (Table 1). To avoid possible amplification of contaminating genomic DNA, primer sets were designed over intron-exon boundaries. The expression of lalpha-HYD, 24-HYD and reference genes GAPDH (glyceraldehyde 3-phosphate dehydrogenase), EEF1A2 (eukaryotic translation elongation factor-1-alpha-2), $R P L-19$ (ribosomal protein L-19) were analyzed by quantitative RT-PCR using the LightCycler ${ }^{\circledR} 480$ instrument and SYBR Green I (Roche Diagnostics, Mannheim, Germany), according to manufacturer instructions. Each sample was analyzed in a total reaction volume of $20 \mu \mathrm{L}$, consisting of $2 \mu \mathrm{L} 10 \mathrm{X}$ diluted cDNA, $10 \mu \mathrm{L}$ SYBR Green I Master $2 \mathrm{X}$ and $2 \mathrm{mM}$ each primer and water. The reaction setup for all primers was: $95^{\circ} \mathrm{C}$ for $2 \mathrm{~min}$; 40 cycles of $95^{\circ} \mathrm{C}$ for $10 \mathrm{~s}, 60^{\circ} \mathrm{C}$ for $10 \mathrm{~s}$ and $72^{\circ} \mathrm{C}$ for $6 \mathrm{~s}$; and a final extension at $72.0^{\circ} \mathrm{C}$ for $3 \mathrm{~min}$. Melting curve analysis was performed immediately after PCR reaction. Every RT-qPCR experiment included a negative control (non-template control) and a calibrator, which is a pool from all samples for a known gene $(G A P D H)$. The expression was recorded as cycle threshold $(\mathrm{Ct})$.

\begin{tabular}{|c|c|c|c|c|}
\hline Gene & NCBI (Gene ID) & Local & Primer sequence & Product (bp) \\
\hline \multirow[t]{2}{*}{ lalpha-HYD } & 539630 & Exon 6 & 5'-TCTCCTGGGCTCTGTATGAA-3' & 221 \\
\hline & & Exon 7 & 5'-TTCACCCACACAAATGTCTC-3' & \\
\hline \multirow[t]{2}{*}{ 24-HYD } & 540080 & Exon 3 & 5'-TGGACGACAAAATCAACGAG-3' & 140 \\
\hline & & Exon 5 & 5'-CTCATACAGCACAAGGCAGA-3' & \\
\hline \multirow[t]{2}{*}{ GAPDH } & 281181 & Exon 1 & 5'-GGCGTGAACCACGAGAAGTATAA-3' & 194 \\
\hline & & Exon 2 & 5'-CCCTCCACGATGCCAAAGT-3' & \\
\hline \multirow[t]{2}{*}{ EEFI } & 282220 & Exon 6 & 5'-GCAGCCATTGTGGAGATG-3' & 196 \\
\hline & & Exon 7 & 5'-ACTTGCCCGCCTTCTGTG-3' & \\
\hline \multirow[t]{2}{*}{$R P L-19$} & 510615 & Exon 1 & 5'-GAAATCGCCAATGCCAAC-3' & \\
\hline & & Exon 2 & 5'-GAGCCTTGTCTGCCTTCA-3' & 410 \\
\hline
\end{tabular}

The efficiency for each gene and sample was determined by linear regression analysis of the fluorescence data obtained with quantitative real-time PCR through the LinRegPCR software (Ramakers et al., 2003). The amount of mRNA $\left(\mathrm{R}_{0}\right)$ and the amplification efficiency was calculated with equations 1,2 and 3 .

$$
\begin{array}{cr}
\log R=\log (E+1) \times n+\log R_{0} ; \text { intercept }=\log R_{b} \text { slope }=\log [E+1] & (\text { Equation 1) } \\
R_{0}=10^{\text {Intercept }} & \text { (Equation 2) } \\
E=10^{\text {Slope }}-1 & \text { (Equation 3) }
\end{array}
$$

From the efficiency of individual samples, the observed Cts were adjusted for a general efficiency, defined as 2.0 (Equation 4). Thus, all the following analyses had the same base efficiency of 2.0 .

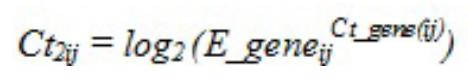

where, $C t_{2 i j}$ is $C t$ sample ij corrected for efficiency 2.0; E_gene ${ }_{i j}{ }^{C t g e n e(i j)}$ is the actual efficiency calculated by the LingRegPCR, high $\mathrm{Ct}$ sample for gene $\mathrm{ij}$. 
A mathematical model (Equation 5) that includes the fixed effect of the reference genes (GAPDH, EEF1A2 and RPL-19) and a random effect associated with the natural variability of the individual sampled was used to obtain the best linear unbiased predictor (BLUP) values of random sample effect. These values were used to obtain an adjusted quantification cycle $(\mathrm{aCt})$ of the target genes (lalpha-HYD and 24-HYD).

$$
Y_{i j}=\mu+g_{i}+a_{j}+e_{i j}
$$

(Equation 5)

where, $Y_{i j}$ is the aCt for reference gene $\mathrm{i}$ in animal $\mathrm{j} ; \mu$ is the overall average $\mathrm{aCt} ; g_{i}$ is the fixed effect of ith gene reference $(i=1, \ldots, 5) ; a_{j}$ is the random effect associated with the animal considering $\mathrm{a}_{\mathrm{j}} \sim \operatorname{NID}\left(0, \sigma_{\mathrm{a}}^{2}\right)$; and $e_{i j}$ is the residual random effect, with $\mathrm{e}_{\mathrm{ij}} \sim \operatorname{NID}\left(0, \sigma_{\mathrm{e}}^{2}\right)$.

After $\mathrm{Ct}$ adjustment, a general linear model that includes the effects of vitamin $\mathrm{D}_{3}$, sunlight exposure, block and interaction between vitamin $\mathrm{D}_{3}$ and sunlight exposure (Equation 6) was used to study gene expression with PROC GLM of SAS (2000). A Tukey test was applied to test the difference between treatments, with a significance level at $\mathrm{P}<0.05$.

$$
Y_{i j k l}=\mu+v_{i}+s_{j}+v s_{i j}+b_{k}+e_{i j k l}
$$

(Equation 6)

where, $Y_{i j k l}$ is the aCt of 1alpha-HYD or 24-HYD; $\mu$ is the constant associated with the model; $v_{i}$ is the effect of vitamin $\mathrm{D}_{3}$, where $\mathrm{i}=0,2$ and $8 ; s_{j}$ is the effect of sunlight exposure, where $\mathrm{j}=0$ and $1 ; v s_{i j}$ is the interaction between vitamin $\mathrm{D}_{3}^{j}$ and sunlight exposure; $b_{k}$ is the effect of block, where $\mathrm{k}=1,2$ and 3 ; and $e_{i j k l}$ is the error associated with each observation.

\section{RESULTS}

Optimal amplification conditions for each gene were established and reaction specificity for each set of primers was verified by melting temperature analysis and agarose gel electrophoresis, in which a single band corresponding to the expected product length was observed for each gene. Melting temperature analysis revealed the absence of nonspecific product amplification.

To correct for possible variation in RNA extraction, quantification and cDNA synthesis efficiency, GAPDH, EEF1A2 and RPL-19 were used as reference genes. All reference genes showed low variation between treatments and exhibited overall average $\mathrm{Ct}$ values of $20.05( \pm 0.66), 24.20( \pm 0.87)$, and $31.04( \pm 0.86)$ cycles, respectively (Table 2$)$.

\begin{tabular}{|c|c|c|c|c|c|c|}
\hline \multirow[t]{3}{*}{ Supplem. } & \multicolumn{6}{|c|}{$\mathrm{Ct}($ means $\pm \mathrm{SE})$} \\
\hline & \multicolumn{2}{|c|}{ GAPDH } & \multicolumn{2}{|c|}{ EEF1A2 } & \multicolumn{2}{|c|}{ RPL-19 } \\
\hline & No shade & With shade & No shade & With shade & No shade & With shade \\
\hline Vit. $0^{1}$ & $20.14(0.53)$ & $20.20(0.61)$ & $24.22(0.95)$ & $24.36(0.73)$ & $32.59(1.70)$ & $31.18(0.37)$ \\
\hline Vit. $2^{2}$ & $20.18(0.69)$ & $20.22(0.72)$ & $24.60(0.87)$ & $24.18(1.05)$ & $31.11(0.45)$ & $30.71(0.85)$ \\
\hline Vit. $8^{3}$ & $19.74(0.64)$ & $19.86(0.76)$ & $24.27(0.76)$ & $23.59(0.88)$ & $30.34(0.67)$ & $30.33(1.10)$ \\
\hline
\end{tabular}

Table 2. mRNA expression (Ct) of reference genes GAPDH, EEF1A2, and RPL-19.

${ }^{1}$ without vitamin $\mathrm{D}_{3}$ feeding; ${ }^{2}$ vitamin $\mathrm{D}_{3}$ supplementation at a dose of $2 \times 10^{6}$ IU for 2 consecutive days preslaughter; ${ }^{3}$ with vitamin $\mathrm{D}_{3}$ supplementation at a dose of $2 \times 10^{6} \mathrm{IU}$ for 8 consecutive days pre-slaughter. 
Different amounts of sunlight exposure did not alter the expression of 1alpha-HYD and 24-HYD genes $(\mathrm{P}>0.05)$. There was no interaction between sunlight exposure conditions and vitamin $\mathrm{D}_{3}$ supplementation. The expression of the lalpha-HYD gene was significantly higher (lower $\mathrm{Ct}$ ) when the animals were supplemented with $2 \times 10^{6} \mathrm{IU}$ vitamin $\mathrm{D}_{3}$ for two and eight consecutive days pre-slaughter, regardless of UV exposure (Table 3). 1alpha-HYD expression was 7.6-fold greater in animals that received supplementation with $2 \times 10^{6} \mathrm{IU}$ vitamin $\mathrm{D}_{3}$ for eight consecutive days prior to slaughter compared to animals without supplementation. Comparison between animals fed for two consecutive days prior to slaughter and those without supplementation showed that the lalpha-HYD gene was 3.6-fold more expressed in animals fed for two days.

Table 3. mRNA expression (aCt) of 1alpha-HYD and 24-HYD genes.

\begin{tabular}{lcc}
\hline Supplem. & lalpha-HYD gene & 24-HYD gene \\
\cline { 2 - 3 } & & $\mathrm{P}>|\mathrm{t}|$ \\
\hline Vit. $0^{1}$ & $29.90(0.56)^{\mathrm{a}}$ & $30.43(0.46)^{\mathrm{a}}$ \\
Vit. $^{2}$ & $28.06(0.48)^{\mathrm{b}}$ & $29.74(0.53)^{\mathrm{ab}}$ \\
Vit. $8^{3}$ & $26.97(0.62)^{\mathrm{b}}$ & $28.60(0.50)^{\mathrm{b}}$ \\
\hline
\end{tabular}

*Least square means of $\mathrm{Ct}$ (standard error); ${ }^{1}$ without vitamin $\mathrm{D}_{3}$ feeding; ${ }^{2}$ vitamin $\mathrm{D}_{3}$ supplementation at a dose of $2 \times 10^{6} \mathrm{IU}$ for 2 consecutive days pre-slaughter; ${ }^{3}$ with vitamin $\mathrm{D}_{3}$ supplementation at a dose of $2 \times 10^{6} \mathrm{IU}$ for 8 consecutive days pre-slaughter. ${ }^{\text {ab }}$ Different lowercase letters in the column within each gene significantly differ by Tukey test $(\mathrm{P}<0.05)$.

Regarding the 24-HYD gene, expression in animals that received supplementation with $2 \times 10^{6} \mathrm{IU}$ vitamin $\mathrm{D}_{3}$ for eight consecutive days prior to slaughter was 3.55 -fold higher when compared to animals without supplementation and did not differ when compared those fed for only 2 days. When the comparison was made between animals fed for two consecutive days prior to slaughter and those without supplementation, there was no effect of supplementation although mean $\mathrm{Ct}$ values were decreased. Importantly, lower $\mathrm{Ct}$ values indicate a higher gene expression.

\section{DISCUSSION}

Supplementation of vitamin $\mathrm{D}_{3}$ to increase meat tenderness in beef cattle shows conflicting results. The rationale for the supplementation is based on the assumption that higher levels of vitamin $\mathrm{D}_{3}$ may contribute to higher calcium levels in plasma and muscle, which would lead to a more active proteolysis by the calpain system.

Previous results from our group, with the same animals used in this study, showed that supplementation with vitamin $\mathrm{D}_{3}$ did not change plasma or muscle calcium levels (Lobo-Jr et al., 2012). This result could be a consequence of the opposing actions of the kidney enzymes (1alpha-HYD and 24-HYD) that control the physiological levels of the active $1,25(\mathrm{OH})_{2} \mathrm{D}_{3}$.

Our results indicated that shortly after vitamin $\mathrm{D}_{3}$ supplementation there was an increase in lalpha-HYD before a rise in 24-HYD gene expression. This is a novel result, since studies in mouse showed decreased lalpha-HYD gene expression concomitantly with increased 24-HYD expression under vitamin $\mathrm{D}_{3}$ supplementation (Henry, 1997; Murayama et 
al., 1999; Healy et al., 2003). This discrepancy could be a consequence of the time of exposure to high levels of vitamin $\mathrm{D}_{3}$. Our study was short term, while most of the literature deals with long-term supplementation.

The increased expression of lalpha-HYD observed after 2 days of supplementation with vitamin $\mathrm{D}_{3}$ could have resulted in higher circulating levels of the active form of $1,25(\mathrm{OH})_{2} \mathrm{D}_{3 ;}$ however, this did not result in higher plasma or muscle calcium levels. A possible explanation for this result may involve changes in the vitamin D receptor (VDR) level or function. There is a number of reports indicating that PTH and calcitonin positively regulate, while $1,25(\mathrm{OH})_{2} \mathrm{D}_{3}$ negatively controls, the expression of lalpha-HYD via VDR (Chen et al. 1993; Murayama et al., 1999). The latter showed that in VDR-deficient mice, there was no negative control of lalpha-HYD expression by the active vitamin D form. Desensitization of the signaling pathway of active vitamin D or defect in the response of VDR has also been reported as a possible cause for lack of downregulation of lalpha-HYD expression under conditions of ectopic administration of the metabolite $1,25(\mathrm{OH})_{2} \mathrm{D}_{3}$ in homozygous Klotho mutant mice (Yoshida et al., 2002). There is also the report of higher and lower expression for lalpha-HYD and 24-HYD, respectively, in VDR null mice (Panda et al., 2004).

Moreover, an apparent insensitivity to vitamin $\mathrm{D}_{3}$ negative regulatory effect on the expression of lalpha-HYD was reported in cells derived from monocytes (Hewison et al., 2003). Those responses appeared to be dependent on variations in the levels of vitamin receptor or receptor ligand ability to recruit coactivators, and the presence of routes that reflect the intracellular response mediated by the receptor. Although those conditions could contribute to the results reported in the present study, all the reports on lalpha-HYD regulation by vitamin $\mathrm{D}_{3}$ are related to gene mutation or knockout in renal cells or extra-renal responses. Those special physiological conditions make it difficult to point out the probable cause of lalpha-HYD expression observed. Furthermore, there has been a well-characterized difference between renal and extra-renal regulation of lalpha-HYD (Zineb et al., 1998).

Vitamin $\mathrm{D}_{3}$ supplementation caused increased expression of the 24-HYD gene. These results corroborate those of another study describing increased expression of 24-HYD as physiological regulation of $1,25(\mathrm{OH})_{2} \mathrm{D}_{3}$, thereby preventing the accumulation of toxic levels of the hormone, even when the expression of lalpha-HYD is enhanced by PTH and calcitonin (Bartella et al., 2004).

Studies using the 24-HYD-null mutant mouse provided the first in vivo evidence that the C-24 pathway, initiated by the $24 H Y D$ enzyme, is the major catabolic process that functions to regulate the physiological levels of $1,25(\mathrm{OH})_{2} \mathrm{D}_{3}$ (St-Arnaud et al., 2000). However, increased expression of 24-HYD detected only after 8 days of supplementation points towards a delayed response. These results suggest that the duration of the experiment or the quantity of vitamin $\mathrm{D}_{3}$ supplied may have not been sufficient to dictate the whole response to supplementation to promote an inverse regulation of the kidney enzymes.

Exposure of monocyte-derived dendritic cells (moDCs) to $1,25(\mathrm{OH})_{2} \mathrm{D}_{3}$ increased 24$H Y D$ gene expression dramatically (up to 3000 -fold) at early time points (day 3 of culture), but then decreased the expression on days 7 and 9 (Hewison et al., 2003). On the other hand, the cited authors reported that $25(\mathrm{OH}) \mathrm{D}_{3}$ had little effect on $24-H Y D$ gene expression on day 3 , but consistent with its conversion to active ligand, induced 24-HYD expression at later time points to a similar degree as with exogenous $1,25(\mathrm{OH})_{2} \mathrm{D}_{3}$. These observations could help explain the delayed response observed for 24-HYD expression in our study. 
The results of this study indicate that short term supplementation of vitamin $\mathrm{D}_{3}$ could result in higher levels of $1,25(\mathrm{OH})_{2} \mathrm{D}_{3}$, since the induction of lalpha-HYD gene expression occurs before any change in 24-HYD expression. However, the lack of increased calcium levels in plasma or muscle indicates that further studies are necessary to investigate the role of the receptor in the regulation of vitamin $\mathrm{D}_{3}$ activity.

\section{ACKNOWLEDGMENTS}

Research supported by FAPESP (\#2008/01986-9) and CNPq research fellowships. The field experimental procedures and samples from the animals were made possible by funding from FAPESP (Grant \#2006/06963-1). LL Coutinho and GB Mourão are recipients of CNPq Research Productivity Scholarships.

\section{REFERENCES}

Barletta F, Dhawan P and Christakos S (2004). Integration of hormone signaling in the regulation of human $25(\mathrm{OH}) \mathrm{D}_{3}$ 24-hydroxylase transcription. Am. J. Physiol. Endocrinol. Metab. 286: E598-E608.

Bondi AA (1988). Nutricion Animal. Acribia, Zaragoza.

Chen KS, Prahl JM and DeLuca HF (1993). Isolation and expression of human 1,25-dihydroxyvitamin $\mathrm{D}_{3}$ 24-hydroxylase cDNA. Proc. Natl. Acad. Sci. U. S. A. 90: 4543-4547.

Gaman PM and Sherrington KB (1981). Science of Food: An Introduction to Food Science Nutrition and Microbiology. 2nd ed. Pergamon Press, Oxford.

Healy KD, Zella JB, Prahl JM and DeLuca HF (2003). Regulation of the murine renal vitamin D receptor by 1,25-dihydroxyvitamin $\mathrm{D}_{3}$ and calcium. Proc. Natl. Acad. Sci. U. S. A. 100: 9733-9737.

Henry HL (1997). The 25-hydroxyvitamin D 1alpha-hydroxylase. In: Vitamin D (Feldman D, Glorieux FH and Pike JW, eds.). Academic Press, San Diego, 57-68.

Hewison M, Freeman L, Hughes SV, Evans KN, et al. (2003). Differential regulation of vitamin D receptor and its ligand in human monocyte-derived dendritic cells. J. Immunol. 170: 5382-5390.

Jones G, Strugnell SA and DeLuca HF (1998). Current understanding of the molecular actions of vitamin D. Physiol. Rev. 78: 1193-1231.

Lobo-Jr AR, Delgado EF, Mourão GB, Pedreira ACMS, et al. (2012). Interaction of dietary vitamin $\mathrm{D}_{3}$ and sunlight exposure on B. indicus cattle: Animal performance, carcass traits, and meat quality. Livest. Sci. 145: 196-204.

Murayama A, Takeyama K, Kitanaka S, Kodera Y, et al. (1999). Positive and negative regulations of the renal 25 -hydroxyvitamin $\mathrm{D}_{3} 1 \alpha$-hydroxylase gene by parathyroid hormone, calcitonin and $1 \alpha, 25(\mathrm{OH})_{2} \mathrm{D}_{3}$ in intact animals. Endocrinology 140: 2224-2231.

Omdahl JL, Morris HA and May BK (2002). Hydroxylase enzymes of the vitamin D pathway: expression, function, and regulation. Аnпи. Rev. Nutr. 22: 139-166.

Panda DK, Miao D, Bolivar I, Li J, et al. (2004). Inactivation of the 25-hydroxyvitamin D 1alpha-hydroxylase and vitamin $\mathrm{D}$ receptor demonstrates independent and interdependent effects of calcium and vitamin D on skeletal and mineral homeostasis. J. Biol. Chem. 279: 16754-16766.

Ramakers C, Ruijter JM, Deprez RH and Moorman AF (2003). Assumption-free analysis of quantitative real-time polymerase chain reaction (PCR) data. Neurosci. Lett. 339: 62-66.

Robert KM, Peter AM and Daryl KG (2002). Harper Bioquímica. 9 ed. Editora Ateneu, São Paulo.

SAS (2000). Institute SAS Language and Procedures: Usage (Version 8.1 Ed.). SAS Institute Inc., Cary.

St-Arnaud R, Arabian A, Travers R, Barletta F, et al. (2000). Deficient mineralization of intramembranous bone in vitamin D-24-hydroxylase-ablated mice is due to elevated 1,25-dihydroxyvitamin D and not to the absence of 24,25-dihydroxyvitamin D. Endocrinology 141: 2658-2666.

Yoshida T, Fujimori T and Nabeshima Y (2002). Mediation of unusually high concentrations of 1,25-dihydroxyvitamin D in homozygous klotho mutant mice by increased expression of renal 1 $\alpha$-hydroxylase gene. Endocrinology 143: 683-689.

Zineb R, Zhor B, Odile W and Marthe RR (1998). Distinct, tissue-specific regulation of vitamin D receptor in the intestine, kidney, and skin by dietary calcium and vitamin D. Endocrinology 139: 1844-1852. 